\title{
Сахарова E.B.
}

\section{Роль общественно полезной проектной деятельности младших школьников в нравственном воспитании}

\author{
Sakharova E.V. \\ The role of the public benefit of the project activity \\ of younger schoolboys in moral education
}

В статье рассматривается актуальная проблема использования проектов при организации общественно полезной деятельности младших школьников в соответствии с требованиями ФГОС НОО нового поколения. Представленные результаты диагностики позволяют сделать вывод и обосновать педагогические условия эффективности реализации социальнопреобразующих проектов

Ключевые слова: общественно полезная деятельность, проект, нравственное воспитание

\section{Сахарова Елена Владимировна}

Кандидат педагогических наук, доцент, заведующий кафедрой

Борисоглебский филиал Воронежского

государственного университета

г. Борисоглебск, ул. Народная, 43
The article describes the use of projects in the organization of socially useful activity of younger schoolboys in accordance with the GEF IEO. The results presented here suggest and justify the pedagogical conditions of the effective implementation of the socio-transforming projects

Key words: public benefit activities, project, moral education

\section{Sakharova Elena Vladimirovna}

Candidate of Pedagogic Science, Associate Professor, Head of Department

Borisoglebskii branch of Voronezh state university Borisoglebsk, Narodnaya st., 43

В соответствии с требованиями ФГОС НОО нового поколения общественно полезная деятельность младших школьников является одним из актуальных направлений деятельности образовательных организаций.

Направление и содержание внеурочной работы, связанное с общественно полезной деятельностью, может быть реализовано при использовании следующих видов деятельности: социальное творчество, волонтёрская деятельность, трудовая деятельность и других, с учетом имеющихся в распоряжении ресурсов социокультурной среды, планируемых результатов и специфики образовательной организации.

Общественно полезная деятельность школьников, начиная с начальных классов, должна подготавливать и развивать в детях самостоятельность в организации и реализации собственной индивидуальной, групповой и коллективной деятельностях. 
Как считает Д.И.Фельдштейн, именно в общественно полезной деятельности реализуется потребность ребёнка в самоопределении, самоактуализации, самовыражении, признании взрослыми его активности, нужности (участие в спортивных, творческих кружках, секциях и факультативах, посещение студий, участие в молодежных общественных организациях и т.д.).

Это значит, что во главу угла построения общественно полезной деятельности ставится задача сформировать систему мотивов на основе потребности школьников в самовыражении в общественно оцениваемых делах, потребности в общении, вовлекающем его в систему социальных отношений, потребности быть нужным и полезным окружающему его социуму.

В проектной деятельности создаются оптимальные условия для решения задач духовно-нравственного воспитания младших школьников, поскольку подобного рода знания, чувства и опыт поведения формируются в процессе поиска решения личностно значимых проблем.

Осознание актуальности проблемы для современного образования позволило разработать и реализовать проект «Милосердие» с учащимися начальных классов.

Для диагностики сформированности духовно-нравственных ценностей у учащихся начальных классов и проверки результативности работы по проекту были выбраны методики: «Бланк-цветограмма "Моя жизнь"» и опрос на тему: «Что такое милосердие».

Результаты проведения методики «Бланк-цветограмма "Моя жизнь"» позволили сделать вывод, что наибольшую эмоциональную удовлетворенность обучающиеся данного класса испытывают от общения с близкими людьми и друзьями. Большие положительные эмоции вызывают увлечения и достижения в жизни. Тревожно, что школьные дела и труд не вызывает достаточно большого энтузиазма. Для этих жизненных ценностей характерен разброс цветов, т.е. присутствует вся цветовая палитра. И, наконец, наибольший негатив дети испытывают по отношению к неудачам. В этом случаи есть фиолетовый, коричневый и черный цвета.

Приступая к работе над проектом, было проведено анкетирование детей. Были заданы вопросы «Что такое милосердие?» и «Нужно ли в наше время быть милосердным?» Показательно, что не все дети тогда смогли ответить на поставленные вопросы. Наряду с правильными ответами были и такие: «Надо посмотреть в словаре», «Не знаю».

В конце работы над проектом все участники пришли к выводу, что в наше время необходимо быть милосердным, а значит, оказывать посильную помощь тем, кто в ней нуждается. Делать это можно разными способами. Порой следует проявить внимание к тем, кто живёт рядом, сказать добрые слова или просто улыбнуться.

Также был проведён цикл занятий для выработки умения чувствовать другого человека, осмысливать поступки свои и сверстников, утверждать себя среди других, развивать самокритичность, видеть хорошее в себе и в других, учиться дружить и классные часы: «Что такое толерантность», «Турнир вежливых, внимательных и заботливых». 
Изучение теоретических аспектов изучаемой проблемы и проведение опытно-экспериментальной работы позволяет сделать определённые выводы.

Нравственное воспитание занимает центральное место в формировании личности школьника. Задачи нравственного воспитания очень сложны. Они не могут быть решены при помощи какого-либо одного метода, даже если учитель им отлично владеет. В нравственном воспитании нужно использовать систему методов, лишь в этом случае удается учесть все особенности процесса нравственного формирования, успешно осуществлять его и достигать высокого уровня нравственной воспитанности школьника.

Метод организации общественно полезной деятельности детей приносит наибольшие результаты в формировании у детей ценных мотивов и способов общественного поведения.

Общественно полезная деятельность рассматривается как особый тип деятельности, который является условием, способом формирования личности и необходимым компонентом многоплановой деятельности ребенка, специально организуемой в системе воспитательного процесса.

В проектной деятельности создаются оптимальные условия для решения задач духовно-нравственного воспитания младших школьников, поскольку подобного рода знания, чувства и опыт поведения формируются в процессе поиска решения личностно значимых проблем и осуществления общественнополезной добровольческой деятельности.

При организации внеурочной деятельности в условиях реализации ФГОС второго поколения большое внимание уделено активной общественнополезной деятельности школьников, которая является результатом воспитательных задач третьего уровня.

Третий уровень результатов - получение обучающимся начального опыта самостоятельного общественного действия, формирование у младшего школьника социально приемлемых моделей поведения. Только в самостоятельном общественном действии человек действительно становится (а не просто узнаёт о том, как стать) гражданином, социальным деятелем, свободным человеком.

Образовательной формой, которая, с одной стороны, учит детей находить достойное место своим инициативам в сложно организованном, динамично изменяющемся социуме, а с другой стороны, устойчиво обеспечивает достижение в социальном творчестве школьников воспитательных результатов третьего уровня (получение детьми опыта самостоятельного общественного действия), является социально-образовательный проект.

Осуществление общественно-полезной деятельности младшими школьниками при реализации социально-преобразующих проектов будет эффективным при соблюдении следующих условий:

- востребованность и социальная значимость результатов деятельности, возможность оценить её эффективность;

- участие ребёнка в создании замысла проекта, включающего анализ проблемного поля, личное самоопределение, постановку конкретной цели; 
- опора проекта на коллективно-распределённый характер деятельноСТи;

- образовательное сопровождение всего хода осуществления проекта с позиции обеспечения рефлексии ребёнком используемых средств, полученных результатов, эффективности деятельности, планирования нового цикла.

(C) 2015, Сахарова E.B.

Роль общественно полезной проектной деятельности младших школьников в нравственном воспитании
(C) 2015, Sakharova E.V.

The role of the public benefit of the project activity of younger schoolboys in moral education 